2. Ridge T. Shared medical appointments in diabetes care: A literature review. Diabetes Spectrum 2012;25:72-5.

3. American Academy of Family Physicians. Shared medical appointments/group visits [Internet]. Leawood, Kansas. AAFP. 2018. Available from: https://www.aafp.org/about/ policies/all/shared-medical.html. Accessed June 11, 2018.

4. Careyva B, Salzman B, Plumb E, et al. Patient perceptions of a diabetes group visit experience. J Community Med Health Edu 2012;2:2.

5. Burke RE, O'Grady ET. Group visits hold great potential for improving diabetes care and outcomes, but best practices must be developed. Health Affairs 2012;31:103-9.

doi: 10.3122/jabfm.2018.05.180171

The above letter was referred to the author of the article in question, who offers the following reply.

\section{Re: Wide Gap between Preparation and Scope of Practice of Early Career Family Physicians}

To the Editor: Peterson et al. ${ }^{1}$ have published a stimulating piece that leaves the reader wanting more analysis, which will probably show up in future articles. For all the years since residency education began, a family medicine residency graduate faces a "buyers' market" relative to job opportunities that match one's desired practice. With appropriate guidance from teachers and mentors, residents should be able to clearly write down the values that are important to them, the type of community in which they would hope to practice, and the nature of the patients for whom they would like to care. I have a letter that I wrote in the fall of 1972 with those items and have referred to it as my career has gone along.

This report in the journal raises the issue of the early differentiation of residents in their desired scope of practice. Instead of a "generic stem cell" graduate, we have seen an increase in early choice making, almost immediately after the match has happened. One of the purposes of residency education is to expose residents to patients and communities and practice styles of colleagues that will influence their thinking about future choices. Deciding too early risks closing off learning.

If, however, the problem is, in part, corporate medicine in large cities deciding that fragmented care is what it wants to deliver, those systems should be confronted with the analyses and data that show that family doctors can and will provide comprehensive and integrated care at lower cost and higher quality. In the end, if large systems cannot figure out how to let family doctors "practice at the top of their degree," then graduates can walk away, organize efforts to demand changes in their organization, or find another health system that will. Like unions in the early 20th century that demanded working conditions that met their needs, family doctors can collectively confront organizations that will not let us practice in the ways we are trained. But that discussion needs to happen among family doctors of all ages and generations. Solidarity is power.

My concern is that self-differentiation, economic and family issues, and what is portrayed as a comfortable life may influence choice. Variety is not only the spice of life, it has been shown to positively affect physician happiness. We do not want to see a dissatisfied generation of family doctors stuck in monotonous care systems. If large systems that respect diversity of practice and clinical autonomy and encourage innovation are featured and celebrated by graduates, the industrialized health systems will have to change toward that model of care if they want to recruit new family doctors. Word has a way of getting out.

John J. Frey III, MD University of Wisconsin-Madison, Santa Fe, NM

To see this article online, please go to: http://jabfm.org/content/ 31/5/829. full.

\section{Reference}

1. Peterson LE, Fang B, Puffer JC, Bazemore AW. Wide gap between. preparation and scope of practice of early career family physicians J Am Board Fam Med. 2018;31:181-82.

doi: 10.3122/jabfm.2018.05.180142

The above letter was referred to the author of the article in question, who offers the following reply.

\section{Response: Re: Wide Gap between Preparation and Scope of Practice of Early Career Family Physicians}

To the Editor: I read with interest Dr. Frey's comments spurred by my recent article $^{1}$ on differences between preparation for and provision of different clinical activities seemingly central to the core of family medicine. Like many people, my refrigerator door has many magnets, among my favorites is one the American Academy of Family Physicians sent me that says, "PROUD FAMILY DOC." Lately I have been wondering what it means to be a proud family physician. Our specialty still holds the archetype of the proud family physician as one who is long standing in their community, provides cradle-to-grave care, and will care for their patients when and where they need them. This phenotype is becoming the rare exception to a growing list of "-ists" who care for one part of a patient or only care for them in limited settings.

Should I be proud of my broad-scope training if I do not use it? Should I be proud of the care I provide my patients even if I no longer provide inpatient care, deliver babies, and rarely see children in the office? Should I be proud of my mindset and values? Should I be proud of the history of our specialty when the present may not honor it?

The core of what a family physician is, seems under question. Dr. Frey suggests that family physicians rally together to take down health care systems or create their own. Such collective actions require a sense of community and common purpose that seems to be 